\title{
Qohelet as liminal intellectualism
}

\begin{tabular}{|c|c|}
\hline \multicolumn{2}{|c|}{$\begin{array}{l}\text { Authors: } \\
\text { Ananda Geyser-Fouche }{ }^{1} \\
\text { Lerato L.D. Mokoena }\end{array}$} \\
\hline \multicolumn{2}{|c|}{$\begin{array}{l}\text { Affiliations: } \\
\text { }{ }^{1} \text { Department Old Testament } \\
\text { and Hebrew Scriptures, } \\
\text { Faculty of Theology and } \\
\text { Religion, University of } \\
\text { Pretoria, Pretoria, South Africa }\end{array}$} \\
\hline \multicolumn{2}{|c|}{$\begin{array}{l}\text { Research Project Registration: } \\
\text { Project Leader: A.B. } \\
\text { Geyser-Fouchè } \\
\text { Project Number: } 1258230\end{array}$} \\
\hline \multicolumn{2}{|c|}{$\begin{array}{l}\text { Description: } \\
\text { This research is part of the } \\
\text { project, 'Second Temple } \\
\text { Literature and Qumran', } \\
\text { directed by Dr Ananda } \\
\text { Geyser-Fouche of the } \\
\text { Department Old Testament } \\
\text { Studies, Faculty of Theology, } \\
\text { University of Pretoria. }\end{array}$} \\
\hline \multicolumn{2}{|c|}{$\begin{array}{l}\text { Corresponding author: } \\
\text { Ananda Geyser-Fouche, } \\
\text { ananda.geyser-fouche@up. } \\
\text { ac.za }\end{array}$} \\
\hline \multicolumn{2}{|c|}{$\begin{array}{l}\text { Received: } 07 \text { Feb. } 2020 \\
\text { Accepted: } 09 \text { Dec. } 2020 \\
\text { Published: } 05 \text { Feb. } 2021\end{array}$} \\
\hline \multicolumn{2}{|c|}{$\begin{array}{l}\text { How to cite this article: } \\
\text { Geyser-Fouche, A. \& } \\
\text { Mokoena, L.L.D., 2021, } \\
\text { 'Qohelet as liminal } \\
\text { intellectualism', } \\
\text { HTS Teologiese Studies/ } \\
\text { Theological Studies } \\
\text { 77(4), a5954. https://doi. } \\
\text { org/10.4102/hts.v77i4.5954 }\end{array}$} \\
\hline \multicolumn{2}{|c|}{$\begin{array}{l}\text { Copyright: } \\
\text { (c) 2021. The Authors. } \\
\text { Licensee: AOSIS. This } \\
\text { is licensed under the } \\
\text { Creative Commons } \\
\text { Attribution License. }\end{array}$} \\
\hline \multicolumn{2}{|l|}{ Read online: } \\
\hline 回解回: & $\begin{array}{l}\text { Scan this QR } \\
\text { code with your } \\
\text { smart phone or } \\
\text { mobile device } \\
\text { to read online. }\end{array}$ \\
\hline
\end{tabular}

Qohelet is one of the most fascinating books in the Hebrew Bible because it falls outside of the confides of what it is deemed as orthodox in terms of genre, literary components and theology. Considered in both antiquity and contemporary interpretations as Wisdom Literature, the book holds rich material to be interpreted and classified in a myriad of ways. It is no secret that Qohelet is an idiosyncratic scholar whose position is defined by unusualness, to define it as defiance would be extreme. As traditional renderings of liminality are often but not always limited to spatiality and time, here liminality is defined as an intellectual exercise. The decision to locate Qohelet as a liminal intellectual is informed by the epistemology encountered in the book if the consensus is that Qohelet existed in post-exilic Israel and that the book borders mostly around philosophical themes and ideas. The aim of this article is to outline and state how, when and why Qohelet becomes a liminal intellectual. This article subsequently borrows from the discipline of anthropology to illuminate how such a position is attainable and possible through a reading of Qohelet with an intersection of Arnold van Gennep's conception of liminality that traditionally speaks to the margins and structures of positions to how we use some of those tools of analysis to construct a liminality, which privileges knowledge production and encompasses so much more.

Contribution: This article contributes to the ongoing arsenal of interdisciplinary studies which fits and embraces the scope of the journal.

Keywords: liminality; Qohelet; spatiality; separation; transition; absolutism.

\section{Introduction}

Liminality was first proposed by Arnold van Gennep (1960) in his magnum opus Rites of Passage even though he did not use the word 'liminality' in a technical sense. The aim of this article is to use Van Gennep's ideas and to see whether it can be applied to the book of Ecclesiastes (Qohelet) because the content of book reflects detachment from typical Yahwistic wisdom literature (separation), a re-evaluation of conventional epistemology (transition) and an offering of liminality in the Hebrew canon (incorporation). This offering on liminality in the Old Testament (henceforth Hebrew Bible) with a special emphasis on Qohelet is to show by drawing from the experiences of Qohelet and that of the times that there was a break in patterns of thought, systems that governed, traditions and literature output.

This article assumes the position of being in consensus with studies surrounding Qohelet and liminality involving certain distinctions that (1) Qohelet was an idiosyncratic scholar, (2) Qohelet's version of wisdom is starkly different from that of the predecessors, (3) Qohelet operates in a domain of breakage and therefore should be qualified and inducted into the school of liminality as an intellectual that espouses similar ideals.

Not all discussions about liminality will be borrowed from anthropology as we will also embark on a journey to realise elements of liminality in Ancient Israel and the Hebrew Bible on their respective selves. It is inevitable to technically speak of liminality and not invoke Van Gennep; the anthropological jargon and interests will arise where necessary.

\section{Tracing liminality}

Admitting that perhaps the concept already existed but was not yet rendered a technical term, Arnold van Gennep (1960), a sociologist, first used the term 'liminality'. Van Gennep (1960:1) explains that every society as it moves from lower to higher levels of civilisation becomes accentuated and distinct with clearly marked social divisions. These divisions become markers and have levels of passages one must fulfil. These are the rite of passages. He documents in his book a number of them, namely pregnancy and childbirth, birth and childhood, initiation rites, betrothal and marriage and funerals. These rites have clearly marked ceremonies whose purpose is to enable the individual to 'pass' from one stage to the next. 
In a wider degree, Van Gennep (1960:3) also argued that the universe is also governed by a periodicity, which has repercussions on human life, with stages and transitions, movements forward and periods of relative inactivity. These can include celestial changes. Van Gennep (1960:4-6) classifies the development into two types: sympathetic and contagious. He explains sympathetic rites as based on reciprocal belief, opposite on opposite, container on contained, image and real object, etc. The latter being rites that are transmissible through direct contact or distance.

Victor Turner's famous expression (cf. Thomassen 2014:89), 'betwixt and between' situation or object, has opened up space for ambiguity in use and meaning where liminality can be applied to both single individuals, larger groups, a whole society and even civilisations. There is also a temporal dimension to liminality that can relate to moments (sudden events), periods (chronology) and epochs (generations) (Thomassen 2014:89). On the one hand, the temporal dimensions of liminality, which are the focus of this article, are constituted as follows: in a moment a person may experience traumatic events such as death, divorce or illness; on the other hand, a group of people may graduate, attend a wedding, go through war, etc. In a society, there can be an event such as a natural disaster, invasion where normality disappears and hierarchies become rearranged. In a period, a society can go through war or revolutionary periods. In an epoch, there could be political instability or intellectual confusion (Thomassen 2014:90).

The essence of liminality is spatiality; it is no coincidence that Van Gennep begins his book with territorial passages because 'spatial and geographical progression correlates with the ritual marking of a cultural passage' (Thomassen 2014:91). The concept is multi- or inter-disciplinary. Liminality found a home outside of the study of rites of passages with the work of Victor Turner who whilst in a liminal space himself stumbled upon the work of Van Gennep (Thomassen 2009:14). Turner further expanded liminality as not only an 'in-between' period but also the human reactions to those liminal spaces through thought and experience.

In his works Turner (1974, 1987) argued on liminal experiences. Firstly, he maintains (1974) that liminal experiences in modern consumerist societies have been replaced by 'limonoid moments' where creativity and uncertainty unfold in art and leisure activities. In the latter work (1987), Turner argues that the pilgrimage shares aspects of liminality because participants distance themselves (through movement) from mundane structures and social identities leading to a homogenisation of status and a strong sense of Communitas (Thomassen 2009:15).

Liminality can thus be viewed as the 'performance' or 'processes' of a society. The key element being transition. Liminality is not liminality without movement. There are a few things, which can be further deduced from Turner's work (Thomassen 2009:18), namely that, firstly liminality can sometime be framed or produced by a certain liminal experience in a certain spatial context. Secondly, that sometimes liminality can be pure where both spatial and temporal coordinates are in play and it simply becomes inevitable. Lastly, liminality can also be artificially produced the same way it can happen without anyone planning for it; individuals and groups can consciously search for liminal positions, that is the Qumran sectarian movement and Qohelet, respectively. Nevertheless, the conclusion is that there are degrees to liminality.

The simplest meaning of the term can thus be an intermediate, in-between space or transition between phases, or an intangible construct in a state of ambiguity $(\mathrm{Ng} \& \mathrm{Lim}$ 2018:76). Although originating in anthropology, the concept has been widely used interdisciplinarily. Psychologists and therapists use liminality during consultations (therapeutic sessions) so as to help individuals to come to grips with lifechanging experiences. Recently, liminality became prominent because the concept helps commentators to explain and comment on societies who go through liminal situations when experiencing a collapse of order (Thomassen 2009:19).

Thomassen (2009:19) used the terms 'axial moments' or 'axial renaissance' when referring to larger-scale groups or civilisations. Karl Jaspers (in Thomassen 2009:20) famously describes the axial age as 'it was an in-between period between two structured world views and between two rounds of empire building'; it was an age of creativity where 'man asks radical questions', and where the 'unquestioned grasp on life is loosened' (Thomassen 2009:3); 'it was an age of uncertainty, where possibilities lie open; it was a period where individuals rise to the test and new leadership figures arise; finally, referring to the spatial coordinates, the axial 'leaps' all happened in in-between areas between larger civilisations, in liminal places: not at the centres, nor outside reach of main civilisational centres but exactly at the margins, and quite systematically so at that'.

The axial age as described by Jaspers bears some liminality; in terms of epistemology, the centre's grip loosened and the margin can now articulate for its own, on its own with its own. This according to Thomassen (2009:20) has a bearing on the view of history as not governed by structure but rather has a 'flow' or 'moments' in what Van Gennep refers to as 'periodicity' where there is a loosening of structures and new ones emerge, a period characterised by questioning, problematising, reformulations, eradications and recreations.

\section{Liminality in the Hebrew Bible?}

Mesopotamian mythology expressed fluidity and movement between the earth and the netherworld, meaning that movement back and forth between two worlds was possible (Krouwer 2015:16). In contrast, Israelite religion grew more and more monolithic; it's theology more defined and syncretic elements began to fall through the cracks. In Ancient Israelite mythology, a person could not exist in two worlds, movement from the present world to the 'next' was permanent and there was no in-betweenness, no continuum. 
There was no subscription to the thought of a continuum between the present world and the 'next' as it may be found for instance in Mesopotamian or African mythology (cf. Mutwa \& Larsen 1996:20; Tutuola 1961:5-6). In the Hebrew Bible, liminality is often depicted as dangerous; hence, the Torah always stresses boundaries and dualism. Death descends upon those who transcend these boundaries, only those with divine permission or those who were ritually pure could cross over into the liminal territory. Stahl (1995:34) argued that the Decalogue (10 Commandments) functions as a hinge in this balancing act between closeness and distance. It provides communication but keeps Israel at a safe distance with God. Liminality in the Hebrew Bible is mostly illustrated in spatial or geographical terms, hardly as an intellectual exercise.

There are instances where although monolithic, Israelite religion displayed characteristics of liminality. Liminality became a necessity for instances where regular grammar could not capture certain events or occurrences could not be explained otherwise. The longstanding belief was that a person could not exist between two worlds at the same time; however, people could experience a liminal event or enter into a liminal space (Krouwer 2015:16). Krouwer (2015:17) further argues that the essence of liminality in the Hebrew Bible was separation and states, 'separation is one of the original connotations contained in the word translated from the Hebrew root 'קדש' as 'holy'. Israel is a holy nation (separate from other nations), and its cultic practices are also set apart. Holiness then became a character of distinctiveness'. A category that creates order close. Although they function in a liminal space, they are open to otherworldly messages through their minds and spirits.

Even in an established order like the religion and theology of Ancient Israel, core beliefs are not expressed homogenously; there is bound to be a breakaway when reality and ideas begin to collide. When events, ideas or feelings did not fit in the established order, that rupture created discomfort and they were often discarded. Krouwer (2015:17) argues that a fixed construction of categories creates conditions of possibility for the existence of liminality and further supports his argument by quoting Neumann (2012:474) who argues that: 'where pure categories do not apply, feelings of insecurity and danger ensue'. Ideas sometimes refuse statis and outgrow times and circumstances; it is in that instance where they begin to erode or begin to contradict the reality, which gave birth to them.

Stahl (1995:13) investigates how times where the divine attempts to forge a human connection as pivotal moments as liminal. A number of these moments may be ephemeral or enigmatic, that is Moses and his family returning to Egypt from Midan and encountered a God-like being (Ex 4:24-26), the two versions of the Creation narrative, or Noah and the flood (Gn 9:1-17). Stahl notes that the hallmark of these liminal moments are that they are concerned with transition as focal functional points.
Kaunda (2016a:52-53) uses the Exodus narrative and how it can be read in the light of a theo-decolonial paradigm, suggesting a theo-liminal pedagogy. I cite this example deliberately because Kaunda describes the wilderness metaphor as an example of reality-creating pedagogy. Kaunda (2016) describes the wilderness as a liminal space of re-learning and recreation of an identity, that is Yahwisticcentred and says:

The wilderness wanderings show that the Hebrew mind emancipation occurred in the liminal space between Egypt and the Promised Land; between the old and the new; between what they were as slaves and what they would become as a free nation. (p. 61)

The Israelites who were now far removed from their known reality had to make sense of their new one and establish it into the existing order separate from its geographical origins.

\section{Qohelet as liminal intellectual}

The liminality argued for in Qohelet is that which transcends the given epistemological order of traditional law and wisdom, starkly different from that in the Torah and slightly different with Proverbs, Lamentations, Job, etc. because it not only questions basic tenets of Israelite wisdom but it also has a creative anti-structural process and creates a space for intellectual work where dominant social discourse can be critiqued. The liminal stage is where the creative process takes place, knowledge is created, structures critiqued, discourse reimagined and at the end of this liminal period, the liminal intellectual is then reintegrated into a society where they live with these new accepted forms. Qohelet, if dated to the Hellenistic era, found itself in an intellectual liminal stage, ${ }^{1}$ a period characterised by a number of changes and movements, geographical changes, linguistic changes, intellectual changes, etc. It was the end of one era and the dawn of a new one for the Judeans that meant new administration and new cultural elements (Sneed 2012:252).

The context and social location of Qohelet creates the literary possibilities for liminality because the social circumstances Qohelet finds itself in is a moment of great pedagogical opportunity (Baumgarten 2002:1). This liminal period can be classified as temporal because Hellenism was a sudden event resulting from a long social process of political instability, which resulted in the intensive infiltration of the Israelite territory (Collins 2005:1; cf. Hengel 1973). Qohelet reacts to

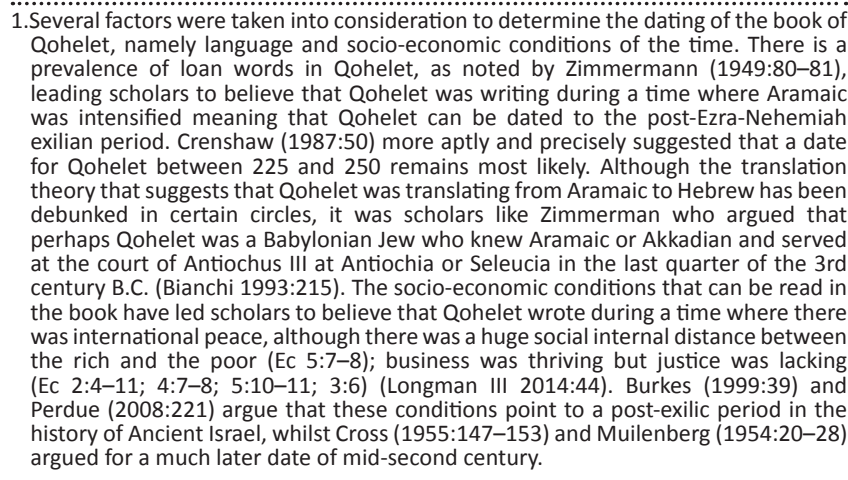
Qohelet, namely language and socio-economic conditions of the time. There is a prevalence of loan words in Qohelet, as noted by Zimmermann (1949:80-81), leading scholars to believe that Qohelet was writing during a time where Aramaic was intensified meaning that Qohelet can be dated to the post-Ezra-Nehemiah exilian period. Crenshaw (1987:50) more aptly and precisely suggested that a date for Qohelet between 225 and 250 remains most likely. Although the translation theory that suggests that Qohelet was translating from Aramaic to Hebrew has been debunked in certain circles, it was scholars like Zimmerman who argued that at the court of Antis a Babylonian Jew who knew Aramaic or Akkadian and served cer the 3rd the rich and the poor (Ec 5:7-8); business was thriving but justice was lacking (EC 2:4-11; 4:7-8; 5:10-11; 3:6) (Longman III 2014:44). Burkes (1999:39) and history of Ancient Israel, whilst Cross (1955:147-153) and Muilenberg (1954:20-28) argued for a much later date of mid-second century. 
the liminal circumstances of political instability and intellectual confusion to revisit the basic tenets of existence, wisdom and faith. The epistemology of Qohelet represents a unique tradition in wisdom literature that detaches itself from the typical wisdom that only wants to defend the authenticity of Yahwism. Liminal intellectuals were going through a period of transition to reformulate their wisdom as a new breed of tradition perhaps even incorporating a few of the previous elements.

The first sign of liminality in Qohelet that informs the broader epistemology is that of empire influence and subjugation, the transition of one ruler to another (i.e. Ec 4:1; 10:4-5; 20), is a shifting season, a transitional point in time where Israel is under a new administration from the Persian rule to Hellenism. Ancient Israel is no stranger to turbulence with its long history of having been subjected to a series of world empires since its inception as a unified nation right through to the Babylonian exile and return. We hardly see any change in the ideas and theology the nation subscribed to, besides that we actually see Israel's theology being uniformly formed and refined; the biggest threat has been syncretism but never a total restructuring (see Feldman 2006:74-75; Hengel 1973, 1980:51; Holladay 2002:66).

Stuck between a place that they do not seek to assimilate into and not being able to return home is the liminal space or period that effects change; that in-betweenness prepares them to be active participants in their new society where old elements and ways of thinking are not wholly discarded but challenged or can no longer be fully incorporated (Thomassen 2014:89). According to Turner, we often think of liminality in terms of rituals that enforce social norms, continuing that which is conservative, and he advanced on that idea and argued that liminality can also be anti-structural or have a creative process, it can be used in revolutionary rebellious ways. In this liminal space, revolutionary behaviour is encouraged and the persons can critique the dominant social discourses.

Qohelet can be located at this juncture; it is a book characterised by difference and idiosyncrasy highly influenced by the period of the exile. The period of the exile in its very existence is enough breeding ground for a society to revaluate all that encompasses its existence because of the turbulence it experiences. Liminality can vary from space (spatial liminality) to knowledge (intellectual liminality) and in Qohelet the special emphasis is on how the exilic period affected knowledge production and application in Ancient Israel. Qohelet presents a renewed way to interpret and engage with wisdom. Wisdom that was once solely a virtue for the gods and not accessible to man (Van der Toorn 2007:21) is now presented in Qohelet as accessible and attainable through empirical ways (i.e. searching, engaging through dialogue, a practice we see amongst philosophers, or experience).

Van der Toorn (2007:23-27) notes that ancient wisdom that was meant to be formal instruction assembled by scribes and associated with manuals found predominantly in written texts can be observed in Qohelet, moving from being a revelation to being an experience. Given that during the exile, the population of the people captured by colonial forces largely comprised the literate because the peasants had to work the land. The scribalisation of wisdom was to make it an object of veneration, encrypting the message, to give off the illusion that it is accessible to few, revealed by God to those he has chosen.

The scribalisation of wisdom presented an inevitable crisis. Loader (1979:120) noted that this system of inscribing wisdom became a dogmatic system, which later would find itself in conflict with time and the scripts would set times contradict reality. This is because what seemed to be right to man, would be wrong for the gods and that would create some sort of cognitive dissonance. Loader (1979:121) further notes that when the systemisation of wisdom entered Israel (i.e. Pr 1-9) wisdom began to lose its relativity with time and totally collapsed the notion of causality. The scribalisation of wisdom was characterised by absolutism and stagnation, although its effect in the lives of people is not negated as far as they regarded it, however that the text was beginning to be in conflict with the context.

The indication of the tension between relativity and causality can be observed in a few of Qohelet's utterances (i.e. Ec 3:16-17 New International Version (NIV)):

Whatever is has already been, and what will be has been before; and God will call the past to account.

And I saw something else under the sun: In the place of judgment wickedness was there, in the place of justice - wickedness was there, From the New International Version book of Ecclesiastes.

Qohelet here alludes to the concept of eternal recurrence that nothing is new, what has been there was once there before and further says that, wickedness is present in both the place of judgement and justice. This is a stark contrast we see in the systemised and scribalised wisdom, for instance in Proverbs (24:25-25) 'When justice is done, it brings joy to the righteous but terror to evil doers' and Proverbs (29:7) 'The righteous care about justice for the poor, but the wicked have no such concern'. There is a clear divergence in a number of fundamental core values such as justice, truth, righteousness and how their interpretation has evolved.

Qohelet had become disillusioned with the reality they find themselves in Ecclesiastes 3:19-20: 'Everything is meaningless. All go to the same place; all come from dust, and to dust they all return'. A scandalous statement from a time where predestination was privileged and a purpose for life and God was privileged as the source of life, wisdom, truth and justice. Liminality has often been viewed as that which helps with the continuing of the accepted social order, rituals of continuum; here we see it as being anti-structural through not only its work but also intellect.

Except for Qohelet's reaction against traditional wisdom, which placed him in a space of liminality, the repetition of 
the concept of hebel ${ }^{2}$ can be highlighted as an example of liminality as it transitions from the traditional connotes of pessimism to active affirmation. From the standard definition of hebel being defined as a masculine noun, literally translated as 'breathe and/or vapour' (Sneed 2012:154), Qohelet uses neither of these in the use of the term in the book. The reason for this can be because Qohelet not only uses the term as prescriptive but also uses it as descriptive. Fields (1975:160) illustrates how Qohelet uses hebel in various ways such as in Ecclesiastes 2:15-16 the 'vanity' of human wisdom; Ecclesiastes 2:19-21 the 'vanity' of human labour; Ecclesiastes 2:26 the 'vanity' of human purpose; Ecclesiastes 4:4 the 'vanity' of human rivalry; Ecclesiastes 4:7 the 'vanity' of human avarice (greed); Ecclesiastes 4:16 the 'vanity' of human fame; Ecclesiastes 5:20 the 'vanity' of human insatiety; Ecclesiastes 6:9 the 'vanity' of human coveting; Ecclesiastes 7:6 the 'vanity' of human frivolity; and Ecclesiastes 8:10,14 the 'vanity' of human awards. Qohelet uses hebel to describe the state of humanity and activities humanity is preoccupied with.

Fox (1989:36) stands in consensus with the above postulation that hebel in Qohelet is understood as a 'concept that applies to all occurrences'. This makes sense because the denotation 'all is hebel' as in 'all is vapour and breathe' would simply not fit all contexts. Given the contexts in which hebel is used to denote acts of temporal existence and fleeting, it is of my opinion that hebel was preoccupied with life that remains idle, unchanged and subject to monotony without meaning or purpose. It seems at this juncture, Qohelet was more concerned with the value of values, a much deeper sense of the word where futile human activities are not the primary subject of interrogation but that why they exist and why they have to be performed in the first instance. Not why the vanity of human wisdom exists but why the schism within the attainment of wisdom exists, not why the vanity of human greed exists but why human greed should be contented to begin with and not why the vanity of human coveting but why humans are not self-sufficient beings that they need to covet exists in the first place.

This interpretation leads to a much more wider understanding of Qohelet's epistemology. Qohelet seems to have not been satisfied with an unexamined life. This goes to show that hebel does not advocate for the nihil of existence but rather a radical imagination and active affirmation. This is remarkably transitionary and in the sphere of liminal intellectual work it is grounded and affirmed. The transition of thought qualifies this intellectual work to be inducted as a liminal activity.

\section{Liminality in an African context}

An example of liminality in our own African context is how gender is articulated in the Ndembu culture in Uganda. The liminal spaces within Ndembu culture were a process that involved withdrawal from the cultural centre (structured

2.According to Anderson (1997:8) ascertained by a computer search the root word hebel appears approximately 86 times in the Hebrew Bible: 69 times as the absolute

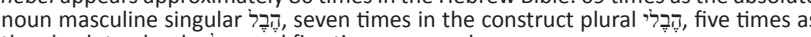
the absolute plural הֶֶֶ, and five times as a verb. society) to engage differently with certain aspects of cultural norms (see Kaunda 2015, 2016a, 2016b, 2016c). The withdrawal from normal society was meant to enable the community to get a better and clear view of cultural elements that were inadequate to upgrade them to make the society more responsive to the changed circumstances. This is also an example of an artificially manufactured liminal space. It is important to note that although the notion of liminality (in the meantime) has been widely used in Western anthropology, much of the recent understanding of the concept emerges from Victor Turner's observations amongst the Ndembu people. In other words, although liminality is a western invented concept, its connotation in its post-Turnerian usage is entrenched with Ndembu thought. The argument is that Turner introduced a new concept in Ndembu culture to conceptualise local ideas that already existed for universal consumption. Turner introduced a new language for scholars to rationalise Ndembu complex thought system. This means that even if we replace the concept with a new one, the idea of Ndembu ritual will remain intact.

\section{Concluding remarks: Waiting for Godot?}

We see the same for Qohelet; the use of the technical term liminality does not introduce a new language for the social process that was already taking place, but rather a new grammar in universal terms to assist to articulate the process for human consumption. This means that Qohelet has long been identified as a revolutionary thinker of the time, liminality just borrows us tools of organising and assembling:
Estragon: Let's go.
Vladimir: We can't
Estragon: Why not?
Vladimir: We're waiting for Godot. (Moinao 2016:1)

The pressing question seems to be how can a liminal moment or space be identified? I suggest that a liminal intellectual space can be identified whilst waiting for Godot and trying to imagine the possibility of Syphisus happy. These two moments are pivotal as they encompass the absurdity and turbulence of life as we continue to create and recreate new ways we can come to re-evaluate existential meaning. Waiting for Godot is a play by Samuel Becket in which two characters Estragon and Vladimir have a series of conversations about all things existence and meaning whilst waiting for Godot who never arrives. Siphysus is from the philosophical essay of Albert Camus, a Greek mythological figure condemned to rolling a boulder up a hill in the depths of Hades for cheating death, a task seemingly meaningless (Moinao 2016:2).

From these two instances we are immediately confronted with what is absurd, trifle, monotonous and meaningless. From the work of Becket we see how he captures the pessimistic world of the two tramps through refrain Estragon and Vladimir are in the middle of nowhere in hopeless anticipation for someone who never arrives an analogy that 
can be used to illuminate the plight of human kind, the tendency to seek inherent value and meaning and the inability to find any because they lack thereof, human beings are constantly trying to make sense of life. Qohelet laments on this and states:

$[N]$ o one can comprehend what goes on under the sun. Despite his efforts to search it out, man cannot discover its meaning. Even if he claims to know he cannot fully comprehend, New International Version book of Ecclesiastes. (8:17)

The futile search for meaning leads to a conclusion that all is hebel!

The condition of Waiting for Godot and Hebel on face value present a gloomy, empty world, with no salvation, doomed to hopeless waiting and searching. Like the opening of Waiting for Godot 'Nothing is to be done' Qohelet begins with the saying 'Hebel! Hebel! All is Hebel!' It seems that time just passes and there is no effective change. Qohelet undertakes the task of finding life-affirming possibilities in the wait, in the in between, in the transition, in the strife, in the toil, which is pushing up a boulder. In that moment Qohelet could choose not to respond to world at all, actively resist change, life becomes a repetition and the metaphorical role of Syphysis is assumed or creates in presence becoming a liminal intellectual.

Our societies have simply grown too complex - or at least, with the shift to postmodernism we have discovered that social life is too complex. However, we can articulate a new way of looking at intellectual liminality as a zone of thinking that stretches beyond borders. To better understand why and how I suggest that Qohelet is an example of liminal intellectualism, in this case, defined as a 'moment' or a breakaway from conventional wisdom in Ancient Israel through an investigation of the social setting and background of wisdom literature. The term 'wise' in Ancient Israel has always been reserved or restricted to a certain class or group of people. Described as an acquired skill, wisdom would be applied to a variety of specialised occupations, that is seamanship, professional mourning, snake charming, house building, craftsmanship, magic and deviation and the interpretation of dreams (Whybray 1974:134).

All these specialised occupations are underpinned by specialised functions. However, there was also a wisdom tradition where a sage or sages produced a certain kind of literature characterised as wisdom literature different from those mentioned in Jeremiah 18:18 (priests, prophets and sages), which Crenshaw (1981:27-29) argues that they should be clearly distinguished. This is because he believed that their work reflected a unified worldview different from those of the priests and prophets.

Azize (2003:123) refers to the genre of Qohelet as 'critique'. Although not clear whether Qohelet's predecessors were familiar with this kind of literature, I believe Qohelet nevertheless hints in this direction through satire, rhetoric and re-evaluation of old values. However, this line of thought can be accounted for through what Chia (1988:182) refers to as 'liminal intellectualism' as the appropriate term for the classification of Qohelet's thought and genre. In Chia's (1988:182-183) study on liminal intellectualism, he details three stages of this process as described by Van Gennep as (1) separation (pre-liminal), (2) transition (liminal) and (3) incorporation (post-liminal). In the first stage, individuals or groups will detach from a fixed social structure. In the second phase, liminality itself becomes the social setting for the detached groups or individuals; antistructure becomes dominant.

Finally, when the transition is over, in the final stage, the detached groups or individuals are reincorporated into the social structure with a call for new behaviour or a re-evaluation of old values (emphasis added). When taking into cognisance Qohelet's social status (if it exists), social setting, themes, thoughts and conclusions he comes to in the book, it is safe to say that he and his followers were liminal intellectuals, not only did he sway from the conventional school of thought but he also sought to re-evaluate social structures and values as they were by reinventing himself as not only a sage but a philosopher as well.

\section{Acknowledgements Competing interests}

The authors have declared that no competing interests exist.

\section{Authors' contribution}

All authors contributed equally to this work.

\section{Ethical considerations}

The article followed all ethical standards for a research without direct contact with human or animal subjects.

\section{Funding information}

This article represents a reworked version of one aspect from the PhD thesis of Lerato LD Mokoena, titled, 'Another Meaning Is Possible: A Re-Reading of hebel in Qohelet', completed under the supervision of Prof. Ananda GeyserFouchè, Department of Old Testament and Hebrew Scriptures, Faculty of Theology and Religion, University of Pretoria. This thesis was funded by a grant from the National Institute for the Humanities and Social Sciences (NIHSS).

\section{Data availability}

Data sharing is not applicable to this article as no new data were created or analysed in this study.

\section{Disclaimer}

The views and opinions expressed in this article are those of the authors and do not necessarily reflect the official policy or position of any affiliated agency of the authors. 


\section{References}

Anderson, W.H., 1997, 'Skepticism and ironic correlations in the joy statements of Qohelet?', Doctoral dissertation, University of Glasgow.

Azize, J., 2003, 'The genre of Qohelet', Davar Logos 2(2), 123-138.

Baumgarten, A.I., 2002, 'Were the Greeks different? If so, why?', in J.L. Kugel (ed.), Shem in the tents of Japhet: Essays on the encounter of Judaism and Hellenism, pp. 1-30, Supplements to the Journal for the study of Judaism.

Bianchi, F., 1993, 'The language of Qohelet: A bibliographical survey', Zeitschrift für die alttestamentliche Wissenschaft 105(2), 210-223. https://doi.org/10.1515/ zatw.1993.105.2.210

Burkes, S., 1999, 'Wisdom and law: Choosing life in Ben Sira and Barcuch', Journal for the Study of Judaism in the Persian, Hellenistic, and Roman Period 30(3), 253-276. https://doi.org/10.1163/157006399X00172

Chia, P.P.Y., 1988, 'The thought of Qohelet: Its structures, its sequential, unfolding, and its position in Israel's theology', Unpublished PhD thesis, University of Sheffield.

Collins, J.J., 2005, Jewish Cult and Hellenistic Culture essays on the Jewish encounte with Hellenism and Roman rule, Supplements to the Journal for the study of Judaism, v. 100

Crenshaw, J.L., 1981, Old Testament wisdom: An introduction, p. 144, John Knox Press, Atlanta, GA.

Crenshaw, J.L., 1987, Ecclesiastes: A commentary, Westminster Press (Old Testamen Library), Philadelphia, PA.

Cross, F.M., 1955, 'The oldest manuscripts from Qumran', Journal of Biblical Literature 74(3), 147-172. https://doi.org/10.2307/3261464

Feldman, L., 2006, Judaism and Hellenism reconsidered, Brill, Leiden.

Fields, W.W., 1975, 'Ecclesiastes: Koheleth's quest for life's meaning', Doctoral dissertation, Grace Theological Seminary.

Fox, M.V., 1989, Qohelet and his contradictions, Almond Press, Journal for the study of the old testament supplement series, 71, Sheffield.

Hengel, M., 1973, Judaism and Hellenism (2 vols), vol. 1, p. 19, Fortress Press, Philadelphia, PA.

Hengel, M., 1980, Jews, Greeks, and Barbarians, Fortress Press.

Holladay, R., 2002, Hellenism in the fragmentary Hellenistic Jewish authors: Resonance and resistance, pp. 66-91, Brill, Leiden.

Kaunda, C.J., 2015, 'Betrayed by cultural heritage: Liminality, ambiguous sexuality and Ndembu cultural change - An African ecclesia-ethic of openness', Alternation Special Edition 14(14), 22-44.

Kaunda, C.J., 2016a, 'The wilderness wanderings: A theo-liminal pedagogy for mind decolonisation in African Christianity', Acta Theologica 36(1), 52-69. https://doi. org/10.4314/actat.v36i1.4

Kaunda, C.J., 2016b, 'Enabling liminality prophetic witness to xenophobia: Proposing a missiological spirit response for the church in South Africa', Koers 81(1), 1-9. https://doi.org/10.19108/KOERS.81.1.2217

Kaunda, C.J., 2017, 'Ndembu cultural liminality, terrains of gender contestation: Reconceptualising Zambian Pentecostalism as liminal spaces', HTS Teologiese Studies/Theological Studies 73(3), 3718. https://doi.org/ 10.4102/hts.v73i3.3718
Kaunda, M.M. \& Kaunda, C.J., 2016, 'Infunkutu - The Bemba sexual dance as women's sexual agency', Journal of Theology for Southern Africa 155(Special Issue), 159-175.

Krouwer, D.J., 2015, 'Moses and liminality', Electronic thesis and dissertations, p. 348, University of Denver.

Loader, J.A., 1979, Polar structures in the book of Qohelet, Beihefte zur Zeitschrift für die Alttestamentliche Wissenschaft, 152, Walter de Gruyter, Berlin.

Longman III, T., 2014, 'Qohelet as Solomon: 'For what can anyone who comes after the king do?', (Ecclesiastes 2:12) in K. Dell \& W. Kynes (eds.), Reading Ecclesiastes intertextually, Library of Hebrew Bible/Old testament studies, 587, pp. 42-57.

Moinao, W., 2016, 'A study of existential nihilism in the book of Ecclesiastes and Samuel becket's waiting for Godot', South Asian Journal of Multidisciplinary Studies (SAJMS) 2(2), 1-7.

Muilenburg, J., 1954, 'A Qohelet scroll from Qumran', Bulletin of the American Schools of Oriental Research 135, 20-28. https://doi.org/10.2307/1355543

Mutwa, C.V.M. \& Larsen, S., 1996, Zulu Shaman: Dreams, prophecies, and mysteries, Destiny Books, VT.

Neumann, I.B., 2012, 'Introduction to the forum on liminality', Review of International Studies 38(2), 473-479. https://doi.org/10.1017/S0260210511000817

Ng, V. \& Lim, J.P., 2018, 'Tracing liminality: A multidisciplinary spatial construct', Journal of Engineering and Architecture 6(1), 76-90.

Perdue, L.G., 2008, The sword and the stylus: An introduction to wisdom in the age of empires, Wm. B. Eerdmans Publishing.

Sneed, M., 2012, The politics of Pessimism in Ecclesiastes: A social scientific perspective, no. 12, Society of Biblical Literature.

Stahl, N., 1995, Law and liminality in the Bible, Sheffield Academic Press, Sheffield.

Thomassen, B., 2009, 'Uses and meanings of liminality', International Political Anthropology 2(1), 1-27.

Thomassen, B., 2014, Liminality and the modern: Living through the inbetween, Ashgate, New York, NY.

Turner, V., 1970, The ritual process: Structure and anti-structure, Routledge and Kegan Paul, London.

Turner, V., 1974, 'Liminal to limonoid, in play, flow, and ritual: An essay in comparative symbology', Rice Institute Pamphlet-Rice University Studies 60(3), 53-92.

Turner, V., 1987, 'Betwixt and between: The liminal period in rites of passage', in M. Little, L.C. Hahdi \& S. Foster (eds.), Betwixt and between: Patterns of masculine and feminine initiation, pp. 3-19, Open Court Publishing Company, Pem, Illinois.

Tutuola, A., 1961, The palm-wine drinkard, Faber \& Faber, London.

Van der Toorn, K., 2007, 'Why wisdom became a secret: On wisdom as a written genre', in C. Richard (ed.), Wisdom literature in Mesopotamia and Israel, pp. 21-33, Brill, Leiden.

Van Gennep, A., 1960, Rites of passage, University of Chicago Press, Chicago, IL.

Whybray, R.N., 1974, The intellectual tradition in the old testament, BZAW, 135, Walter de Gruyter, Berlin.

Zimmermann, F., 1949, 'The question of Hebrew in Qohelet', The Jewish Quarterly Review 40(1), 79-102. 